\title{
History Of
}

\section{RACCOONS}

\section{In Saskatchewan}

\author{
by C. STUART HOUSTON and MARY I. HOUSTON*
}

On four trips in 1972 , we saw a total nine dead raccoons on Saskatchewan ads. Since we had not ourselves seen a ccoon, dead or alive, in our many pusands of miles of travel yearly, this ggested an increase in the numbers of is species. Our personal observations re as follows:

1. Three miles east of Leslie, May 20. 2. Three miles east and 7 miles south Southey, May 21.

3. Between Bulyea and Earl Grey, ay 21 (a large pregnant female, three hes the weight of the others, had been led the preceding night).

4. Near Delisle, July 3.

5. Near Hitchcock, August 14.

6. Near Roche Percee, August 14.

7. Two miles east of Redvers, August

8. One mile north of Whitewood, Ocber 17.

9. Three miles west of Wauchope, Ocber 17

From the late 1920's until the early 60 's, the raccoons seemed largely nfined to the valleys of the Souris and 'Appelle river systems. They like to near water and stream valleys are ir favourite habitat. Of the eight road ls above, six are near these two valley tems, suggesting that these are still ir areas of greatest abundance.

Daniel Harmon in 1820 had not enuntered raccoons on the Assiniboine, an or Saskatchewan Rivers, for he d it is "never found farther north an about latitude forty-eight." 4 In

29, Richardson stated that it was bund as far north as Red River, in itude $50^{\circ}$, from which quarter about e hundred skins are procured anally by the Hudson's Bay Company."

3 University Drive, Saskatoon, Saskatchewan
The first mention of the raccoon in Saskatchewan, to our knowledge, was in the report of the Saskatchewan Game Commissioner for the year ending June 30, 1919:

"Mr. W. V. Hemingway, of Poplar Grove, reports that a raccoon was trapped in the poultry house of James May, section 3-14-2 west of the 2 nd meridian and that the skin is still in possession of the trapper. As this animal is not considered to be a native of the province the record is of scientific interest." (The location was the banks of the Pipestone Valley, about seven miles north and four miles east of Langbank.)

The report of the Saskatchewan Game Commissioner for the year ending April 30,1925 , contains the following statement:

"The raccoon is not recognized as a Saskatchewan fur bearer, therefore it is worthy of note that at least three specimens were taken in the province last year. One at Carlyle, the pelt of which is in the provincial museum: another a few miles from Melfort, and of the third, Mr. S. Lee Fraser of Tate writes, under date of March 31, 1925, as follows: 'One day last week, Mr. W. C. Mackenzie, a farmer living three and a half miles south of here, was shovelling snow from a concrete culvert ... on looking into the culvert he found a full grown raccoon.' ",

Bradshaw added that "These are very interesting records, and in view of the fact that the pelts were taken at such widely distributed points, it would almost appear that for some reason or other the raccoon is extending its range westward." Thus the raccoon first appeared on the annual "Statement showing the number and kinds of furs bought in Saskatchewan" for the fur 
Decade*

$1931-1940$

$1941-1950$

$1951-1960$

$1961-1970$

$1971-1972$
Skins sold per year

$5,14,16,26,19,3,2,5,4,1$

$0,0,8,1,6,9,55,174,2,8$,

$23,18,9,17,27,54,21,40,39,82$

$92,60,74,69,43,109,173,134,179,289$

174,290
Average

Total Per Year

$95-10$

263

330

1222

464

*Each year begins on July 1 and ends June 30 .

year ending June 30, 1925; four raccoons were listed at an average value of $\$ 4$.

For the next three years, the Saskatchewan trapping totals were one, five and four, respectively, with the average value at $\$ 5.00$ for the latter two years. Totals were not published for the years ending in 1929 and 1930. For the next four decades, raccoon skin sales were as follows:

From 1947 through 1962, prices averaged below $\$ 3.00$. The lowest price per pelt was $\$ 1.05$ in 1952; the highest was $\$ 9.04$ in 1969 .

Coincident with the increase in numbers documented above, there has been an extension of the raccoon's range in Saskatchewan. A single record for Meadow Lake was the only record north of the Qu'Appelle Valley mapped by Beck in 1958.' (Beck omitted the original records from Tate and Melfort). Harris reported two records for the Saskatoon area, as well as records from Semans and Raymore, between 1967 and 1971."

In June, 1971, Frank Hough and Scott Hale found a fresh roadkill on Highway 14 where it meets Clarence Avenue just south of Saskatoon, and

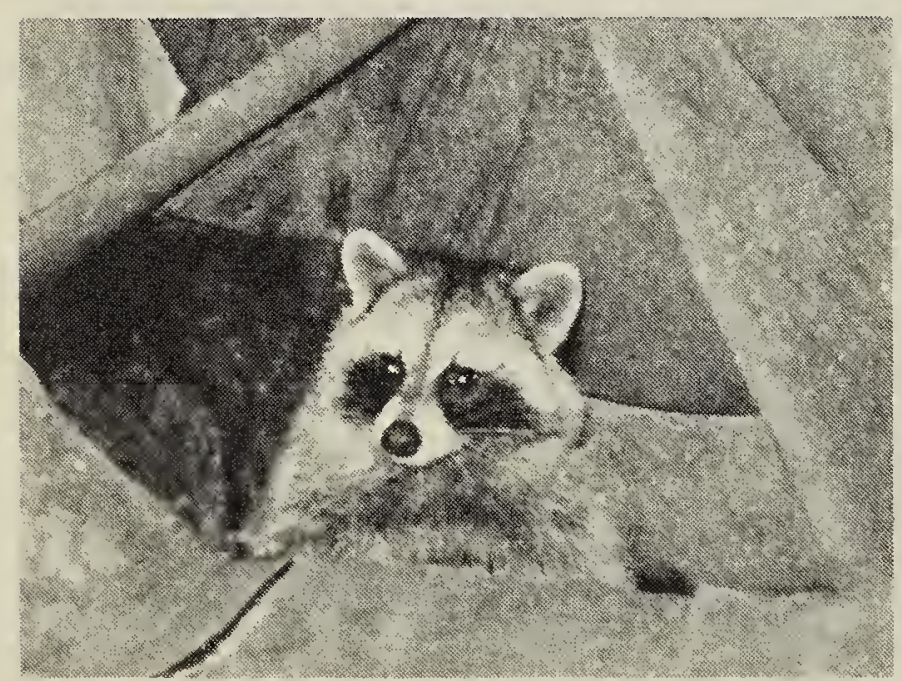

Raccoon

Christine Skinner they also found raccoon tracks along th river in the summer of 1972. As yet, w have not encountered raccoon predatio of nearby bluebird houses, though this said to be common along bluebird hous routes in the United States.

A more northerly record came to $\mathrm{m}$ from W. L. Anderson of Christophe Lake. In mid-March, 1972, while retu ning home from a carnival after mic night, a raccoon ran from the ditch an across the road in full view 20 yar away. He studied its tracks carefully an realized he had seen similar tracks o several occasions in the past two year He also learned that Bill Crothers hat shot a raccoon near his home Christopher Lake in the winter of 196 70 and Gilbert Charles had trapped or on the Little Red River, 7 miles west Northside, the same winter.

Almost as far north was the raccoc seen 3 miles south and 1 mile west Mullingar on September 15, 1968, Ralph Cowell.

Since the raccoon is largely a noctu nal mammal, naturalists should learn recognize its distinctive tracks, with fi prominent toes on each foot. The pho shows a raccoon staring (at Christi Skinner) from the bottom of the blow of a Case separator near Indian Head

'BECK, W. H. 1958. A guide to Saskatchen Mammals. Sask. Nat. Hist. Soc. Spec. Pub. Regina. 52 pp.

'BRADSHAW, F. 1920. Report of the Chief $G$ Guardian. In Annual Report Dept. Agricult Regina. p. 28.

"BRADSHAW, F. 1925. Report of the Clice Ga Guardian. In Ann. Rep. Dept. Agricultu Regina, pp. 22-23.

${ }^{4}$ HARMON, D. W. 1820. A Journal of voyages c travels in the interior of North America. Flagg : Gould, Andover, $432 \mathrm{pp}$.

"HARRIS, W. C. 1971. Some recent Saskatche raccoon records. Blue Jay 29: 214.

"RICHARDSON, John. 1829. Fanna Borea americana, Part 1, Mammalia. John Murray, Li don, pp. 36-37. 